\title{
ОСОБИСТІСНЕ СПРИЙМАННЯ ХУДОЖНІХ ОБРАЗІВ ІСТОРИЧНОЇ ПОДІЕВОСТІ В МУЗИЦІ СУЧАСНИХ УКРАЇНСЬКИХ КОМПОЗИТОРІВ
}

\author{
Крепак К. В.
}

\section{ВСТУП}

Світосприйняття сучасною людиною нових тенденцій та реалізацій у культурному просторі історичної подієвості духовних потреб стає об'єктом гострих дискусій. Протягом часу в суспільства виникають прагнення до змін в музиці, які об'єктивно пов'язані з політичними, економічними та соціальними змінами. Вони впливають на загальний духовний і культурний розвиток молодого покоління, змінюють запит на сприймання художнього образу, змінюють творчий шлях сучасних митців, стилістику та самобутність музичної мови. Національна Спілка композиторів України з великою відповідальністю та професіоналізмом продовжує спрямування та розвиток сучасної композиторської школи, нерозривно пов'язаної з історією і культурою українського народу, яка проявляє свою творчу креативність у різних напрямах музичної культури. Є. Станкович, Г. Гаврилець, Л. Дичко, В. Степурко, В. Антонюк, В. Рунчак, Т. Оскоменко-Парулава, 3. Алмаші, І. Щербаков, В. Зубицький, С. Зажитько, А. Сташевський та багато іншої цікавої талановитої молоді продовжують розвивати та визначати композиторські напрями, модернізувати погляди історико-стильових моделей, відповідно пристосованих до духу новітнього часу історичної подієвості.

Глобалізаційні процеси, пов'язані 3 історичною подієвістю, стимулюють посилену увагу українських митців до створення сучасного культурного явища - художнього образу, який би становив підвищений інтерес для людського сприйняття, створений глибинною суттю перетворення внутрішнього психологічного розуміння історичних процесів у світовому вимірі. Якісне перетворення загальнолюдського пізнання усвідомлено посилює опір загальної уніфікації, на тлі якого зростає значення локалізму як способу життя й системи мислення. Локально-цивілізаційний підхід до культури допомагає долати ідеологічний монізм, притаманний формаційному підходу, прокладає шлях до створення синкретичної, багатомірної картини історичної подієвості. Людина як носій локальної культури постає в широкому соціальному контексті у стані постійного діалогу між різними культурними традиціями. Нові принципи концептуалізації, пов'язані зі складною діалектикою глобального і локального, стимулюють відмову 
від однобічних лінеарних трактувань модернізації як руху до наперед визначеної універсальної мети.

Стрімкий розвиток сучасного українського суспільства зумовлює суперечливі за своїм масштабом і характером дії, які породжують розбіжності на всіх рівнях соціуму у всьому діапазоні політичних відносин. Наявність конфліктів у житті кожної людини, у побуті, сім'ї, або у процесі існування та розвитку суспільства держави набула широкого визнання. Перебіг конфліктних відносин людини і світу завжди викликає посилений інтерес. 3 кінця XX ст. і дотепер соціальнополітичні конфлікти стають об'єктом вивчення та дослідження для таких вітчизняних соціологів, як: А. Бандурко, О. Даніл'ян, С. Головаха, О. Стегній, В. Казаков, А. Пойченко. Але, незважаючи на досить значну кількість досліджень у цьому напрямі, у вітчизняній соціологічній науці недостатньо поглиблено розвинута концепція історичного явища соціально-політичний конфлікт. Специфіка розгортання такого конфлікту в Україні пов'язана 3 непослідовністю та суперечливістю розвитку суспільства, тотальним зростанням відчуження, низьким рівнем довіри населення до владних структур.

Підбиваючи підсумок, розуміємо, що соціально-економічна криза торкнулася всіх соціальних інститутів; політична заангажованість усіх верст населення, перевантаження інституціонального простору спричинили почуття соціальної безпорадності, а падіння рівня життя незадоволеність соціальної захищеності в людей. У такому суспільстві активно й рішуче сприймається стан трансформації в музичному мистецтві. Це пов'язано з розвитком історичних подій та формуванням своєї особистої свідомості, 3 матеріальним станом та загальною освіченістю, з різним географічним розташуванням населення тощо.

Нові явища художньої культури народжуються в контексті даної історичної епохи, національної культури, соціальної структури суспільства, своїм народженням і художнім змістом вони являють собою складний «сплав» тимчасового i неминущого, національного i загальнолюдського. Нові художні явища в певному сенсі випереджають свою епоху, оскільки покликані «слугувати» не тільки теперішньому, а й майбутньому. ${ }^{1}$

\section{1. Вплив історичної подієвості на розвиток сучасної української музичної культури кінця XX - початку XXI ст.}

Актуалізація статті присвячена впливу історичної подієвості на розвиток сучасної української музичної культури кінця XX - початку XXI ст., а також впливу соціально-політичних конфліктів на створення

\footnotetext{
${ }^{1}$ Колесникова Л. Художній час як проблема онтології мистецтва : дис. ... канд. філос. наук: 09.00.08. Київ : Київський національний ун-т імені Тараса Шевченка, 2003. 20 с.
} 
нової моделі художньо-образного сприймання історичної подієвості. Відображена модель художнього створення, а саме особистісне бачення історичної подієвості у творчості сучасних українських композиторів.

Актуальність цього дослідження зумовлюється недостатньою кількістю наукових робіт у вітчизняному мистецтвознавстві, у яких упорядковано узагальнювалося питання розвитку вивчення історичної подієвості. Хоча $є$ праці, що містять цінні дані про розвиток окремих жанрів художнього та музичного. Наприклад: «Подієвість у музиці як універсалія художнього часу» А. Івко (Київ, 2002 р.), «Художній час як проблема антології і мистецтва» Л. Колеснікової (Київ, 2003 р.), «Інтонаційний аспект музичної подієвості в контексті викладання аналізу музичних творів у вищий школі» К. Рікман (Тернопіль, Київ, 2005 р.), «Подієвість музичного символу» О. Рябініної (Полтава, 2008 р., с. 74), «Сторінки літературної історії. Краєзнавчий дискус» А. Слюсар (Одеса, 2012 р.).

Критичний аналіз стану суспільства і перспективи наукових досліджень з актуальних проблем на грунті системного підходу виявляє неповноту предмета пізнання історичної подієвості, зумовленою недостатністю цих досліджень, принципів і методів вирішення наукових i практичних завдань. Варто зазначити, що одним із принципів системного підходу $є$ нагромадження знань у процесі формування та розвитку системи знання. Цим підкреслюється активна роль цього чинника в пізнанні та виключається невиправдане нехтування вже існуючими уявленнями та знаннями. Зміни і трансформації, які вносила кожна епоха зі своїми закономірностями розвитку історичної подієвості, впливали на свідомість українського народу. Але він зберіг свої особливості, має своєрідні тенденції культурного та духовного розвитку, що простежуються від найдавніших часів дотепер.

Для українських митців початку XXI ст. актуальності набуває проблематика сучасного бачення світосприйняття, духовного та психологічного оздоровлення суспільства, прагнення до щирості та великого бажання всіма силами зберегти державність України. Відновлення цих людських якостей потрібне для модернізації сучасного суспільства, для розвитку нових цінностей та комунікацій, нових відносин між людьми у сфері мистецтва, отже, і культурних потреб та засобів їх задоволення. Варто зазначити, що такий шлях повернення до національної свідомості та виховання патріотичних почуттів залежить від кожної людини - прагнення до соціальної гармонії, власної гідності, право людини на життя, свободу думки, право на мораль.

Саме тому, на мій погляд, сучасні українські митці, відтворюючи символ правдивості, миру і добра, свідомо в сучасному розумінні розвитку історії звертаються до постаті Кобзаря. 
«Гей, гей, гей, співайте, кобзарі

Співайте так, щоб чули в світі <...> - 3 таким закликом звертається до людей сучасний український композитор Костянтин Крепак у своєму музичному творі «Монолог Кобзаря» для кобзаря - бандуриста та симфонічного оркестру. Композитор складає власний текст до твору, у якому відверто та подієво висловлює своє бажання повернути довіру українському народу. Автор статті невипадково звертається до постаті кобзаря сучасного бачення світосприйняття, у якому ідея музичного твору полягає передусім у духовному та психологічному оздоровленні суспільства, у прагненні до щирості, у великому бажанні всіма силами зберегти державність України.

Кобзарське мистецтво - це культурний феномен українського народу в соціумі свого часу. Воно пронизує чи не всі напрями людської життєдіяльності - від матеріальних потреб до духовних цінностей. Пройшовши великий шлях еволюційного процесу, його сміливо можна вважати народним класичним жанром. Класичним тому, що він немає художніх спотворень, фальші, лицемірства й брехні. Воно побудовано на піднесених духовних та інтелектуальних якостях особистостей.

Відомий сучасний український поет-кобзар Ярослав Чорногуз у своєму «Маніфесті Кобзаря» (муз. К. Крепак) дає чітку визначеність постаті кобзаря сьогодення: «<..> це України вірний син, iї душа правдива $<\ldots>$ », «<..> це нації духовний меч, іiї історії окраса $<\ldots>$ », «<..> хай зазвучить струна жива, розкаже про своїх героїв, хай в серце западуть слова: Кобзар - це не жебрак, а воїн!». Саме тому, на мій погляд, сучасне кобзарство виходить за рамки виконання музичного твору під супровід бандури або кобзи, це може бути музикант будьякого виконавського жанру, головне - створювання художніх образів, високих духовних ідей, справедливих взаємин, почуття гідності, національної свідомості, патріотизму. Із цього погляду варто зазначити, що до спадщини сучасних кобзарів, у такому розумінні, можна віднести творчість низки сучасних українських композиторів: Л. Дичко, Є. Станковича, В. Степурка, В. Антонюка, К. Крепака, Т. ОскоменкоПарулаву, 3. Алмаші, А. Сташевського, І. Щербакова й інших митців.

Отже, музично-культурна діяльність завжди була невід'ємної частиною духовного самоутворення українського народу; у ній узагальнюється досвід нації, втілюється менталітет українства, його моральні якості та духовні ідеали, у якому зберігаються національні традиції музичної культури. Художня мова музичного мистецтва, незважаючи на розвиток українських подієвостей, водночас стає надбанням загальнолюдської музичної культури нації ${ }^{2}$.

\footnotetext{
${ }^{2}$ Стравинский И. Мысли из «Музыкальной поэтики. Статьи и материалы / сост. Л. Дьячкова. Москва : Советский композитор, 1973. 528 с. 
Видатна постать сучасного українського митця Є. Станковича, який у своїй творчості неодноразово звертається до теми історичної подієвості: Симфонія № 2 «Героїчна» (1975р.), Симфонія № 3 « Я стверджуюсь» на слова П. Тичини для соліста, хору і оркестру (1976р.), фольк-опера «Цвіт папороті» (1979р.), «Каддіш-реквієм» для читця, соліста, хору та симфонічного оркестру (1991р.), «Чорна елегія» для хору й оркестру на вірші П. Мовчана (1991р). Його геніальній особистості завжди властиві ідеальне сприймання історичної подієвості, витончене розуміння загальнолюдських потреб суспільства та його запит на художні цінності. Філософія музики композитора може «атрибутивно включати в себе деякі математичні та інші компоненти», на художньому рівні вирішувати проблеми онтологічного, гносеологічного й аксіологічного характеру.

У 1992 р. композитор створює камерний твір для тріо: скрипки, віолончелі та фортепіано, у якому відображає події чернобильської трагедії. Цей програмний твір з'явивився під назвою «Музика рудого лісу». Три частини: «Початок <...>» (“Quasi Preludes”), «Продовження $<\ldots>$..> ("Quasi Ludus"), «Кінець < ..>» ("Quasi Postludio").

€. Станкович майстерно створює картину смертного мовчання лісу, що загинув, природи, яка лишилася життя, у якій немає різноцвіття, пташиних голосів, зруйнована гармонія цілісного. Цю безмовність, таке мовчання та беззвуччя розвитку життєнеобхідних процесів Є. Станкович блискуче вирішує завдяки композиторському таланту. Манера його письма нагадує графічне відображення малюнка. Так, у крайніх частинах твору переважає флажолетна техніка, яку можна порівняти зі штрихом на малюнку, а вузькі, невеличкі гліссандо або розпливчасті п'ятна кластерних співзвуч у фортепіано нагадують п'ятна на холсті. Кожна партія тріо не вертикалізується, вона живе у своєму вимірі: несинхронна метроритміка, несерійна техніка додекафонії, відсутність ладотональних тяжінь. Усе це зберігає характерний для графіки лінійний стиль. Повисли в акустичному просторі звук крапель, тягучі нитки флажолет, монотонні остінатні побудови становлять видиме неживої природи.

Унікальність музичного світобачення та світовідчуття історичної подієвості повною мірою, за допомогою композиторських прийомів та вишуканої інструментовки, передає сучасний український композитор Андрій Сташевський у сюїті для симфонічного оркестру «Древньокиївські фрески». Це програмний твір, у якому дуже тонко відображаються культурні й історичні події стародавньої епохи. ${ }^{3}$ За допомогою тембральних та зображальних композиторських знахідок, 3 використання колоритної гармонічної вертикалі та яскравої мелодики -

\footnotetext{
${ }^{3}$ Івко А. Феномен музичної цілісності в подієвому аспекті. Художня цілісність як феномен музичної творчості та виконавства. Київ : НМАУ ім. П.І. Чайковського, 2005. Вип. 48. С. 57-64.
} 
складає повне та правдиве враження духовних загальнолюдських вимірів Київської Русі. Наприклад, назви частин: «Биліни», «Награвання», «Розваги скоморохів», «На славу Русі Київської», у точності відтворюють дух того часу. Важливу роль у житті людей відігравали церковні передзвони, які сповіщали про наступ ворога, пожежу, скликали людей на віче. Андрій Сташевський блискучо створює атмосферу церковних передзвонів в одній із частин під назвою «Набат. Дзвони святої Софії», завдяки використанню вишуканої оркестровки та динамічних контрастів. ${ }^{4}$

Яскравим прикладом української духовної музики, яка продовжує унікальну традицію класичного українського хорового співу, є твори сучасного українського композитора Лесі Дичко, їі твори широко відомі в усьому світі. Вона є автором кантат, ораторій «І нарекоша ім'я Київ» на тексти літописів, «Достойно є» 3 Літургії № 2, «Прохальна ектенія» 3 Української святої літургії, «Псалом 67», хоровий твір для жіночого хору a cappella; «Хваліте Господа $з$ небес» для тенора, мецо-сопрано й органа; «Тобі співаємо, Тебе благословимо», «Благослови, душе моя, Господа» - духовна музика (українською мовою) для сопрано й органа, інші твори. Літургії Л. Дичко - це спроба поєднання канонічних текстів Служби Божої з новітніми проявами музичного мислення, твори, які формують музично-естетичний простір сучасної музики українського православ'я.

Л. Дичко - композитор, яка наділена приголомшливим чуттям насолоди від кожної митті буття, від усього, що іiі оточує. Саме нестримана воля пізнання атмосфери часу, історичних подієвостей, ландшафтів, фресок, книжної графіки, обрису писанок тощо приводить композитора Л. Дичко до правдивого, всебічно аргументованого відображення. ${ }^{5}$

Творчість Л. Дичко «втілює характерні риси нашої нації: ліричність, щирість, м'якість, ніжність та емоційність, схвильованість, поривання до дії». Завжди сучасна позиція композитора переживає суспільнополітичні події, які втілені в колорит гармонії та мелодики, щирості та відвертості художнього замислу музичних образів.

Сучасна українська музика ілюструє множинність творчих рішень, у яких відбиваються ознаки історичної подієвості. Для кожного художника історична подієвість сприймається зі своїм особистим світосприйняттям, специфічними особливостями художніх прийомів, 3 насиченими та суперечливими художніми образами, які характеризуються неоднозначними рівнями мислення, 3 перегрупуванням естетичних ознак, появою певних прикмет і особливостей. Так, наприклад, фортепіанна

\footnotetext{
${ }^{4}$ Рікман К. Інтонаційний аспект музичної подієвості у контексті викладання аналізу музичних творів у вищій школі. Тернопіль ; Київ, 2005.

Гордійчук М. М. Леся Дичко / М.М. Гордійчук. - К.: Муз. Україна, 1978. - 78 с. 
мініатюра «Помаранчевий рай» В. Степурко асоціюється 3 подіями української «помаранчевої революції» 2004 р. Цей твір за музичним тематизмом нагадує казкові інтонації із творчості С. Прокоф'єва, композитор використовує культурно-історичний контекст, найбільш зручний для сприймання слухачами часу історичної подієвості. ${ }^{6}$

П'єса циклу «Бог скіфів» відсилає наше уявлення до царства скіфів, скіфських божеств, які персоніфікували природні стихії і космічні явища. Часову відстань композитор підкреслює полірегістровістю як одним із варіантів «полі-» у музиці XX ст. Контраст між високим і низьким регістром надає слухачу надзвичайне відчуття, ніби проти нього постають символи дня й ночі, світла і темряви, сну й пробудження. Вдало застосовує i водночас зіставляє акорди, які характеризують войовничу природу скіфів і бога війни скіфів Ареса. Ефект «полі-» забезпечується завчасним показом кожного із пластів окремо.

Сьогодні народ України переживає складний етап історичної подієвості - розв'язання гібридної війни на Донбасі. Майбутнє України, iii незалежність та існування цілком залежать від урегулювання цього політичного конфлікту. Художні образи в музиці українських композиторів, які пов'язані із проблематикою історичної подієвості, відображають особливі та найбільш значущі події українського народу: визвольні війни, розвиток культури та духовної спадщини, особливості народно-побутового життя, чумацький та козацький рух, мистецтво кобзарів тощо. Таке історичне звернення в художню практику сучасними митцями зумовлено соціальними змінами суспільства, підвищеною активністю окремих творчих особистостей, проявами патріотичних настроїв українського народу, процесами трансформації в музичному мистецтві.

\section{2. Особистісне світобачення історичної подієвості композиторами сучасності}

Історично-політичні подієвості сучасної епохи мають особливості свого розвитку: розгортання системи відносин у певному проміжку часу, розгортання політичної боротьби на будь-якому рівні, відношення до сучасного історичного пізнання, переосмислення та переоцінка художніх та естетичних цінностей національних інтересів. Саме глибоке розуміння впливу історичних подієвостей 2014 р. на світогляд та свідомість українського народу дає історичну нагоду сучасним митцям для створення фундаментального пласта академічної класичної музики. ${ }^{7}$

\footnotetext{
${ }^{6}$ Івко А. Аналіз подієвості музичного твору: методологічний контекст. Київське музикознавство. Київ : КДВМУ ім. Р.М. Глієра, 2003. Вип. 10. С. 73-79.

${ }^{7}$ Сунгуров А. Хронотоп как инструмент регионального политического анализа. Полис. 2003. № 6. C. $62-70$
} 
В. Антонюк - один із тих композиторів сучасності, який миттєво відгукнувся на політичну й економічну агресію щодо України, яка перетворюється на воєнні дії протягом п'яти років і завдає нашій державі великих втрат - загибель тисячі людей, зруйновані міста i села ... величезна прірва невизначеності.

Симфонія № 4 «Система Бажань» та Симфонія № 5 «Про війну» - це одночасні цикли, у яких композитор демонструє принцип наскрізного розвитку симфонізму в рамках класичної побудови форми, виразну полігармонічну горизонталь, блискучу оркестровку - як композитор і музикант проявляє свою громадянську позицію щодо подієвостей в Україні в сучасному розвитку світової цивілізації, як патріот, українець, людина великого інтелекту.

Музичний тематизм композитора ллється від душі до самого серця. Теплота звучання інструментів, що виконують соло (гобой, флейта, фагот, челеста, фортепіано), завдяки лірико-драматичному симфонізму передають різноманітне внутрішнє розуміння людського стану в досить неоднозначному розвитку історичної подієвості.

Композитор використовує лірико-романтичні інтонації, забарвлені колоритами тембрального різноманіття ударних та декоративних інструментів (челеста, арфа, дзвони) тощо. Образ ліричного героя молодого, енергійного, закоханого, сучасного - з'являється в кожній симфонії В. Антонюка. Художне вираження композитора завжди представлене свіжими інтонаціями, зрозумілим і лаконічним слухачеві мелодизмом у традиціях С. Прокоф'єва, Я. Сибеліуса, П. Чайковського й ін. В. Антонюк дуже часто віддає ведучу роль фортепіано, арфі, скрипці - соло, кларнету, англійському рожку, що придає мелодизму, особливого тембрового колориту й елегійності ліриці. Його ліричний мелос із витонченим, тремтяче-ніжним мелодизмом несе особистий художній смак, який не має аналогії зі світовими музичними зразками. Драматургічний прийом розвитку тематизму знаходить своє фактурне та гармонічне вираження. Композитор будує складне концепційне навантаження, робить його однією з головних виразних художніх ідей музичного твору, 3 використанням сучасної гармонічної вертикалі: кластерні звучання сучасних акордів, у яких слухач ясно відчуває подих сьогодення. У моментах найвищого емоційного навалу гармонічна вертикаль вибудовувається в лінію оркестрового tutti 3 його густим i насиченим звучанням міді, використовує всю свою міць звукової амплітуди й особливості звучання. Щодо використання композитором великої кількості ударних інструментів (великий барабан, малий барабан, бубен, фруста, там-там, тарілка, томи, трикутник, віброфон, дзвони, ксилофон, літаври), то воно на часі, саме для найкращого висвітлення революційних подій, розгорнутих в Україні із 2013 р. Гонг 
сповіщає про початок або завершення подій, сухий тріск малого барабана створює образи, пов'язані 3 військовими персонажами, звукозображальний ефект, що імітує стрілянину, передає frustama blocco di legno, а часовий вимір звучання дзвонів, дзвіночків, тамбурина матеріалізує час історичної подієвості.

Для більш зрозумілої передачі подій, пов'язаних із соціальнополітичним конфліктом, який призвів до карколомних наслідків у нашій державі, композитор застосовує «метод імітування звуків вулиці засобами музичної інтонації, вербального звучання натовпу (через скандування вигуків, гасел) тощо». ${ }^{8}$

Людське розуміння важливості історичної подієвості політичної ситуації в Україні визвало потребу зафіксувати в музиці цю сторінку історії, уперше в сучасній українській музиці використати даний композиторський прийом.

В. Антонюк - композитор, який не належить до якогось сучасного музичного стилю та напряму. Його творчі пошуки ведуться у 36 музичних жанрах академічної музики з використання всіх існуючих композиторських технік. Симфонії В. Антонюка, хоча й одночасні, але камерними їх назвати не можна, хоча $б$ із причини використання потрійного складу оркестру, а також арфи, фортепіано і всього спектра ударних інструментів. Музика симфоній відокремлюється та відрізняється одна від іншої тематизмом, ритміко-інтонаційним розвитком, але вже 3 перших тактів у музиці ми впізнаємо композиторський стиль завдяки збереженню музичної конструкції та форми, циклічному мисленню, створенню тематичного різноманіття.

В українській культурі, що на початку нового тисячоліття переживає період модернізаційного i постмодернізаційного структурування та національного утвердження цивілізаційних цінностей, виразно проявляються суперечливі, іноді навіть протидійні тенденції розвитку, що є характерною ознакою перехідного суспільства. Художній час найбільш насичених і суперечливих перехідних періодів історії характеризується помітними змінами у співвідношенні між формами та рівнями художнього мислення, перегрупуванням естетичних ознак, появою певних прикмет і особливостей. Так і в художній практиці перехід від однієї парадигми до іншої характеризується суттєвими змінами, зокрема поширенням природної, вільної (за Л. Колесниковою - монтажної) форми композиції творів, появою безсюжетних, безпредметних, атональних творів у музиці, абстрактних форм у скульптурі тощо. ${ }^{9}$

\footnotetext{
${ }^{8}$ Гриценко О. Культурологічні рефлексії ліричності в виконавських інтерпретаціях симфонічної музики Валерія Антонюка : дис. ... канд. філос. наук: 26.00.01. Київ : НМАУ ім. П.І. Чайковського, 2020.

${ }_{9}$ Тормахова В. Современная популярная музыка и фольклор: к проблеме ассимиляции (на примере творчества Энвера Измайлова). Киевское музыковедение. Киев, 2003. Вып. 10. С. 240-253.
} 
Творча особистість Т. Оскоменко-Парулави на науковому рівні досліджується вперше. Ї̈̈ талановитій особистості завжди властиві витончене розуміння загальнолюдських потреб суспільства та його запит щодо художніх цінностей, ідеальне сприймання історичної подієвості, професійне ставлення до служіння мистецтву.

T. Оскоменко-Парулава - сучасний український композитор, диригент, музикознавець, лібретист, педагог, драматург, громадський діяч, член Національної спілки композиторів України, вирізняється гострим реагуванням на життєві колізії часу - громадсько-патріотичним тонусом, обстоюванням гуманістичних ідеалів буття, любов'ю та шаною до народної філософії, втіленої в давні фольклорні традиції, які повертаються в сьогодення, відкидаючи відчуття меншовартості, що прищеплювалось українцям за тоталітарних часів. Завжди сучасна позиція композитора переживає суспільно-політичні події, які втілені в колорит гармонії та мелодики, щирості та відвертості художнього замислу музичних образів.

Композиторський стиль Т. Оскоменко-Парулави поєднує сучасну лексику письма 3 гостро драматизованими звучаннями мелодикогармонійних надбань народних джерел, громадянське начало, що йде від найкращих зразків пісенності із заглибленням у сферу лірикофілософських роздумів особистості. Композитор експериментує з різними музичними i музично-театральними жанрами. Вона - авторка симфонічних, камерно-інструментальних, хорових, вокальних, театральних творів, що писалися як своєрідні музичні щоденники, відгуки на хвилюючі події життя. У своїх вокальних циклах Т. Оскоменко-Парулава репрезентує лірику широкої амплітуди; iii хоровим творам притаманні змістовна глибина, мелодизм, знахідки в тембральному звучанні; обробки народних пісень вирізняються яскравістю національного колориту, оригінальним композиційним рішенням, точністю відбору засобів виразності. Вона плідно займається педагогічною діяльністю не тільки в Україні, а й у Грузії: викладала в музичній школі м. Гагри, потім працювала в Сухумському музичному училищі, а 31992 p. і дотепер викладає в Полтавському музичному училищі імені М. Лисенка (світова музична література, фольклор, композиція). Багато часу композиторка приділяє роботі з оркестровими колективами як диригент, продовжує займатися своєю улюбленою справою - композицією.

Глибоке розуміння історичної подієвості, велика увага до загального розвитку історії людства, обгрунтованість свого особистого ставлення до незворотних процесів - усе це зумовлює своєчасне звернення композитора до героїчних, патріотичних i водночас простих, миролюбних художніх образів українського народу. Тема історичної подієвості у творчості Т. Оскоменко-Парулава з'являється як підсумок 
смислового розуміння важливості соціально-політичних перетворень у духовному та культурному соціумі. Логіка побудови та розвиток композиційних структур композитора, розгортання сюжетнодраматургічної тканини й організація систем метроритмічного поля допомагає автору перебувати у процесі всіх необхідних взаємодій художніх компонентів у створенні картини історичної подієвості.

Опера «Маруся Чурай» (за романом Ліни Костенко) була написана в 1998 р. на лібретто автора - Т. Оскоменко-Парулави. За жанром - лірикопсихологічна драма, що розкривається на широкому історичному тлі.

Події в опері охоплюють історичну подієвість 1648-1653 pp. - часу активної визвольної боротьби проти іноземних поневолювачів козаків, які дали початок формуванню України як держави. У центрі уваги особиста драма кохання легендарної співачки з Полтави Марусі Чурай, дочки сотника Гордія Чурая, страченого поляками за участь у повстанні.

Патріотизм як одне з найглибших почуттів народу не міг не відіграти ролі найактивнішого ферменту-збудника у справі творення нашої усної народнопісенної скарбниці, визначив одну з найширших тем нашого фольклору. Полум'яна, патріотична пристрасть до своєї Батьківщини і не менш вогняне віддане кохання до своєї дівчини утворюють основну ідею музичного твору.

Опера складається із двох дій, по п'ять картин у кожній. Композиторка динамічно розгортає художньо-образну драматургію опери, без зайвих синтементів, використовує українські народні інтонації, танцювальні мелодії, хорові сцени, імітації козацького середовища. На зміну ліричним епізодам головних героїв приходять закличні голосні звуки літавр, сурм, цокіт копит коней. Таке звучання характерної історичної подієвості передає композитор завдяки блискучій інструментовці, тембровим різноманіттям оркестрової партитури. Т. Оскоменко-Парулава знайшла своє глибинне уявлення історичної подієвості визвольної боротьби козацтва XVII ст. й емоційно достовірно передала зміст героїчного минулого, застосувала художні принципи пісенно-фольклорного тематизму засобами новітніх стилістичних імпульсів сучасного мислення, які поєднують музично-естетичні традиції української та європейської академічної музичної мови.

Уміння створювати власні оригінальні концепції, творчо порушувати теми, що хвилюють сучасників, втілювати засобами композиторського мислення проблеми суспільства й особисту драму людини, відтворювати контрасти комічного і трагічного, розкривати погляд людини на світ крізь призму духовного - такі риси творчості притаманні Т. ОскоменкоПарулаві.

Симфонію № 3 «Сповідь» (2012 р.) та Симфонію № 4 «Українська трагічно-тріумфальна» (2016 
музичного розвитку, пов'язані із трагічними подіями національного конфлікту 1992 р. в Абхазії та сучасними подіями в Україні, що подані крізь призму пережитою автором історичної подієвості. Композитор, завдяки виражальним засобам музичної мови, витонченими інтонаціями, зі своїм індивідуальним композиторським почерком, «малює» яскраво і точно картину війни - 3 пострілами, канонадами і хаосом агресії. Обидва твори поєднані загальним закликом: «Не стріляйте, зброєю, словом злим Ви - не стріляйте!». Цей лейтмотив наскрізь проходить через весь розвиток симфонічної драматургії. Ліричні, щирі інтонації розвиваються протягом всього циклу, змінюючись i поступово набуваючи справжнього драматизму, а у трагічній кульмінації - плачу. Авторка використовує в симфоніях як старовинні абхазькі народні пісні, так i короткі цитати українських народних пісень: «Зажурилась Україна, що ніде прожити», «Через поле, через ліс ластівка летіла». Композиторка символізує образ людини різних національностей і оптимістично, 3 великою надією на мир узагальнює висновки симфоній, що стверджують непереможну силу народів держави, які об’єдналися в боротьбі за щасливе майбутнє.

У композиторській діяльності Т. Оскоменко-Парулави спостерігається прагнення до суттєвого оновлення всіх аспектів традиційної академічної культури та виявлення альтернативних засобів виражальності мови, художньо-образної єдності. Стилістика музичного письма композитора вимагає залучення нетрадиційних образів, унікальності задуму, нової стилістики, розгалуженої символіки та семантики.

XXI ст. в музичному мистецтві України завдяки політичним, економічним, соціальним і культурним явищам розгортає новий елемент композиторської творчості - музично-подієвий синтез просторового часу. Поява цілого пласта професійної академічної музики викликає асоціацію та глибокі переживання українських людей, пов'язаних 3 урегулюванням конфлікту 2014 р. ${ }^{10}$

Видатні українські композитори сучасності Г. Гаврилець, В. Антонюк, Л. Дичко, І. Щербаков, В. Степурко, Т. Оскоменко-Парулава, Е. Станкович, М. Скорик, 3. Алмаші, В. Зубицький, В. Рунчак, А. Сташевський породжують синестезію художньо-образного сприйняття драматичного розвитку історичної подієвості. Вони розширюють можливості впливу сучасної музики на слухача і створюють особливу картину національної трагедії без зайвих прикрас та сентиментів - відверто, правдиво, професійно, за допомогою сучасних композиторських технік, полімодальних компонентів інших видів мистецтв: «Сон» - духовний концерт пам’яті жертв Голодомору на вірші Ю. Плаксюка (2008 р.) для

\footnotetext{
${ }^{10}$ Основания регионалистики: Формирование и эволюция историко-культурных зон Европейской России. - СПб., 1999. - С. 63-65. 
чтеця, тенора, органа, хору та симфонічного оркестру, I. Щербакова, «Монолог віків» (2012 р.) В. Степурко, Симфонія № 3 «Сповідь» (2012 р.) Т. Оскоментко-Парулави, Симфонія № 4 «Українська» $(2014$ р.) Т. Оскоментко-Парулави, «Камерна симфонія» (2014р.) К. Крепака, Симфонія № 4 «Система Бажань» (2014р.), Симфонія № 5 «Про війну» (2014р.), Симфонія № 6 «Лемент над прірвою» (2015р.), Симфонія № 7 «Маскарад непобачених снів» (2016 р.) В. Антонюка, «Елегія - спомин» для віолончелі $з$ оркестром (2016 р.) І. Щербакова, Концерт № 2 для віолончелі з оркестром (2016р.) Є. Станковича, Рапсодія «Думка» на вірші Тараса Шевченка (2017 р.) Л. Дичко, «Монолог Кобзаря» (2018 р.) для кобзаря та симфонічного оркестру К. Крепака.

Отже, творчість сучасних українських композиторів стає тим методом, який надає можливість у царині музики осягнути мікро- $\mathrm{i}$ макрокосмос, виявити, збагнути та донести свої відчуття від дотику до багатогранності історичних подієвостей світу. Саме багатомірність парадигми симфонізму зумовлюе та робить актуальним переведення композиторських досліджень із площини музично-теоретичної у площину культурологічну, що дає змогу перенести функції, які виконує культура, на мистецтво, усвідомити значення симфонізму в подоланні кризи культури, сприйняти його парадигму як конструкт, що поширює обрії свідомості на весь часопростір культури і стає проявом духовного буття. Нами встановлено, що одним із проявів екзистенціального підходу до створення власної картини історичної подієвості світу $\epsilon$ застосування композиторами специфічних прийомів, методів, стилів, що створює нову форму функціонування ліричного героя. Персоніфікація (інтонаційними, тембровими, фактурними засобами) головних тем допомагає виконавцеві створювати, а слухачеві відстежувати наскрізний розвиток лейтмотивного «історично-подієвого» матеріалу, проходячи слідом за всіма їхніми перипетіями від першої до останньої ноти партитури симфонії чи клавіру опери, що надає можливість композиторам донести до публіки основний меседж твору - головну ідею, своє бачення, власний коментар - найбільш грунтовно, усебічно та докладно. ${ }^{11}$ Таке поєднання концертного та симфонічного жанрів збагачує та робить багатошаровими партитури симфонічних доробків сучасних українських композиторів.

\section{ВИСНОВКИ}

Сфери особистісного світобачення композиторів сучасності виявляють їхню дотичність до етнокультурних уявлень української традиції та видають їхній генетичний зв'язок 3 українським національним грунтом.

\footnotetext{
11 Колесникова Л. Художній час як проблема онтології мистецтва : дис. ... канд. філос. наук: 09.00.08. Київ : Київський національний ун-т імені Тараса Шевченка, 2003. 20 с.
} 
Композитори використовують усю палітру художніх засобів для досягнення своєї головної мети: привернути увагу людини до людського в ній самій, створити тло для плідних роздумів слухачів, спонукати їх відкрити в собі потайні глибини свідомості, зрозуміти своє місце в цьому світі й усвідомити швидкоплинність часу - історичну подієвість. Картина світу в музичних творах сучасних композиторів $\epsilon$ результатом їхнього певного сприйняття світу, яке породжує дійсність, що існує навколо кожного з нас. Художні образи, які формують українські митці у своїх творах, $є$ основою для освоєння свідомістю слухача складних, передусім моральних колізій сучасного буття.

Підкреслюємо, що музика сучасних українських композиторів Є. Станковича, В. Антонюка, Т. Оскоменко-Порулави, К. Крепака, В. Степурко, Л. Дичко, А. Сташевського послуговується надбаннями різних стильових доктрин, і в їхньому творчому методі можна знайти риси різних музичних напрямів, але всі вони - інструмент для досягнення певної художньої цілі митців - висвітлення історичної подієвості різних епох. Матеріали даного розділу висвітлено в опублікованих статтях автора.

Визначено, якими саме музичними засобами композитори відтворюють свої естетико-художні задуми, щоб передати історичну подієвість різних епох: крім інтонаційно-мовної лінії, ладо-гармонічної палітри, побудови особливого метроритмічного малюнка, ще й завдяки створенню та закріпленню (протягом одного, а іноді й декількох музичних творів) специфічної тембрової лейтхарактеристики за певними фарботонами. Ксилофони, віброфони, дзвони та дзвоники, трикутники створюють образ годинника; використання звуку труби відсилає слухачів до низки образів, пов'язаних із проявом суто чоловічих якостей: схильністю до мандрів, необхідністю участі у військових походах, мужністю, відвагою, здатністю йти на ризик тощо. Щодо інших засобів музичної виразності композитори застосовують єдиний інтонаційний арсенал, репрезентують ритмо-інтонаційно звороти в одних творах та розвивають їх в інших, чим створюють єдине семантико-емоційне поле. Визначаю, що музика сучасних українських композиторів послуговується надбаннями різних стильових доктрин, у їхньому творчому методі можна знайти риси різних музичних напрямів, але всі вони - інструмент для досягнення певної художньої цілі митців - висвітлення історичної подієвості різних епох.

\section{АНОТАЦІЯ}

Проблематика статті пов'язана із процесами розвитку історичних подієвостей, які стимулюють увагу сучасних українських митців до створення сучасного культурного явища - музично-художнього образу. Усе це пов'язано 3 людським сприйняттям, глибинною суттю 
перетворення внутрішнього психологічного розуміння історичних процесів у світовому вимірі. Українська культура стала основою національного духовного поступу. Забезпечено вільний розвиток усіх національно-культурних об'єднань. Художні образи в музиці українських композиторів, які пов'язані із проблематикою історичної подієвості, відображають найбільш особливі та значущі події українського народу: визвольні війни, розвиток культури та духовної спадщини, особливості народно-побутового життя, чумацький та козацький рух, мистецтво кобзарів тощо.

Процес пізнання історичної подієвості надто складний, зумовлений особистісним світосприйняттям глибинних суперечностей у суспільстві, відображений у творчості сучасних українських композиторів, які створюють музично-художні образи та передають свої почуття, що постійно мають змінюватися. Чим менше узгоджуються політичні інтереси з об'єктивними закономірностями розвитку, тим вища ймовірність непередбачуваних історичних подієвостей, усього того, що змогли донести у своїх сучасних музичних творах українські композитори.

Результати дослідження мають посилання на відповідне джерело. У дослідженні були використані загальнонаукові методи викладання матеріалу вчених, мистецтвознавців, як історичного періоду, так i сучасного часу.

\section{ЛІТЕРАТУРА}

1. Гордійчук М. Леся Дичко. Київ : Муз. Україна, 1978. 78 с.

2. Гриценко О. Культурологічні рефлексії ліричності у виконавських інтерпретаціях симфонічної музики Валерія Антонюка : дис. канд. філос. наук: 26.00.01. Київ : НМАУ ім. П.І. Чайковського, 2020.

3. Івко А. Феномен музичної цілісності в подієвому аспекті. Художня цілісність як феномен музичної творчості та виконавства. Київ : НМАУ ім. П.І. Чайковського, 2005. Вип. 48. С. 57-64.

4. Івко А. Аналіз подієвості музичного твору : методологічний контекст. Київське музикознавство. Київ : КДВМУ ім. Р.М. Глієра, 2003. Вип. 10. С. 73-79.

5. Колесникова Л. Художній час як проблема онтології мистецтва : дис. ... канд. філос. наук: 09.00.08. Київ : Київський національний ун-т імені Тараса Шевченка, 2003. 20 с.

6. Основания регионалистики: Формирование и эволюция историкокультурных зон Европейской России. Санкт-Петербург, 1999. С. 63-65.

7. Рікман К. Інтонаційний аспект музичної подієвості у контексті викладання аналізу музичних творів у вищій школі. Тернопіль ; Київ, 2005. 
8. Сунгуров А. Хронотоп как инструмент регионального политического анализа. Полис. 2003. № 6. С. 62-70.

9. Стравинский И. Мысли из «Музыкальной поэтики». Статьи $u$ материалы / сост. Л. Дьячкова. Москва : Советский композитор, 1973. $528 \mathrm{c}$.

10. Тормахова В. Современная популярная музыка и фольклор: к проблеме ассимиляции (на примере творчества Энвера Измайлова). Киевское музыковедение. Киев, 2003. Вып. 10. С. 240-253.

\section{Information about author: \\ Krepak K. V.,}

Graduate Student, Teacher at the Department of Musical Arts and Choreography Educational and Scientific Institute of Culture and Arts of the Luhansk Taras Shevchenko National University 3, Koval str., Poltava, 36014, Ukraine 